\title{
EDITORIAL
}

\section{ASSÉDIO MORAL NO TRABALHO DE ENFERMAGEM}

O fenômeno de sofrimento no trabalho é estudado por diversas disciplinas, inclusive do ponto de vista da saúde do trabalhador. Na enfermagem temos alguns núcleos/grupos de pesquisa que trabalham com esta categoria, o que tem contribuído para ampliar a produção do conhecimento na área da saúde do trabalhador de enfermagem, e que tratam o adoecimento desse trabalhador tanto de forma física quanto psíquica.

No entanto, o fenômeno do assédio moral foi desconhecido e ignorado por muitos até bem pouco tempo, apesar de ter sido imposto aos escravos, desde o tempo da colonização em nosso país. Através de relatos de situações acontecidas no âmbito das organizações (atos perversos, abusivos e corriqueiros do cotidiano) divulgados em pesquisas e na mídia, começaram as discussões e debates entre profissionais de diversas áreas sociais e científicas. Este fato despertou também no trabalhador a motivação da denúncia do fenômeno que está sofrendo.

No Brasil, a primeira Legislação contra o assédio moral é de Iracemápolis, São Paulo, que foi regulada através da promulgação da Lei no 1.163 de 24 de abril de 2000. Nos dias de hoje vários avanços legais estão acontecendo no que concerne à proteção ao trabalhador, embora ainda não tenhamos legislação federal.

O Assédio Moral no Trabalho (AMT) é a exposição de trabalhadores a situação humilhante e constrangedora, de caráter repetitivo e prolongado, durante a jornada de trabalho. Esta interfere na vida dos trabalhadores de modo direto, compromete sua identidade, dignidade e relações afetivas e sociais, ocasionando danos à saúde física e mental que podem evoluir para a incapacidade de trabalhar, o desemprego ou até mesmo a morte. A humilhação, apesar de concreta, é um risco invisível nas relações e condições de trabalho. Isto é o que nos diz a $\operatorname{Dr}^{a}$ Margarida Barreto, médica do trabalho, que em 2000 publicou sua dissertação de mestrado denominada "Uma Jornada de Humilhações”. Outra autora importante que aborda o fenômeno do assédio moral é Marie-France Hirigoyen, psicanalista e vitimóloga; nos diz que o AMT é toda e qualquer conduta abusiva manifestando-se, sobretudo por comportamentos, palavras, atos, gestos e escritos que possam trazer dano à personalidade, à dignidade ou à integridade física do trabalhador, por em perigo seu emprego ou degradar o ambiente de trabalho. Segundo esta autora, o trabalhador não vai morrer por uma relação de causa e efeito devido a essas agressões, mas perde parte de si mesmo, sentindo-se cada vez mais exausto, humilhado e deprimido. O AMT é um sofrimento nas relações de trabalho, portanto, deve-se considerá-lo doença adquirida em razão do ambiente em que é desenvolvida a atividade, com direito a afastamento, de forma semelhante a como acontece no acidente de trabalho e com benefícios pertinentes.

O AMT é muito comum em relações hierárquicas autoritárias, desumanas e sem ética. Quanto à forma, pode ser vertical (descendente ou ascendente) ou horizontal; quanto ao constrangimento, pode ocorrer entre semelhantes ou trabalhadores da mesma categoria, muito comum nas atividades competitivas, ou também pode ser misto.

Na enfermagem encontramos o assédio moral em todos os ambientes de trabalho, desde a área hospitalar, extra-hospitalar e na academia. Pode ser entre colegas de equipe de saúde e de enfermagem, clientes e familiares, professores e alunos. Provavelmente todos nós já vimos e/ou sofremos esta forma de assédio em nossa ambiência laboral.

Quando esta humilhação/constrangimento se torna repetitiva, o assediador/agressor pode desestabilizar emocional e profissionalmente o assediado/agredido, de forma que este perca a autoconfiança e o interesse pelo trabalho, às vezes desencadeando doenças ou agravando as pré-existentes. Outras repercussões à vítima podem ser o isolamento e, em alguns casos, levar ao consumo de álcool ou outras drogas, em pedir demissão ou ser demitido, inclusive por insubordinação.

Para que possamos lutar contra mais esta forma de violência no trabalho é imprescindível resistir, dar visibilidade, denunciar e documentar situações vivenciadas ou conhecidas, opondo-se a instituições e pessoas que ignoram, fingem não ver ou até mesmo encorajam o assédio moral. Resta-nos também a reflexão sobre se estamos na condição de assediados ou de assediadores, e o que devemos fazer para mudar esta situação.

Marcia Tereza Luz Lisboa

Doutora em Enfermagem. Professora Associada do Departamento de Enfermagem Fundamental da Escola de Enfermagem Anna Nery da Universidade Federal do Rio de Janeiro. 


\section{EDITORIAL}

\section{MORAL HAZARD IN NURSING WORK}

The phenomenon of suffering in the workplace is being studied by many disciplines, including by the worker's health point of view. In Nursing we have some research groups that deal with this category, which has being contributing to the enhancement of the knowledge production in field of the nursing personnel's health, dealing with the sicken of these workers both physically and psychically.

However, the phenomenon of moral hazard was unknown an ignored by many people until nowadays, although it has been imposed to the slaves, since the period of colonization in our country. By the influence of the report of situations that take place in the organizations settings (everyday pervert and abusive acts) released in researches and in the media, many debates among professionals of many social and scientific areas are occurring. This fact also arise the motivation for the denunciation of the phenomenon that many workers are suffering.

In Brazil, the first legislation against moral hazard is from Iracemápolis, São Paulo that was regulated through the promulgation of the law 1163 of April 24, 2002. Nowadays, many legal advances are happening regarding the workers' protection, although there's still not a federal legislation.

Moral Hazard at Work (MHT) is the exposure of the workers to a repetitive and long-standing humiliating and embarrassing situation, during the workday. This situation interferes in the workers' life in a direct way, jeopardizing their identity, dignity, love and social relationships, which could lead to damages to the physical and mental health. It may evolve to influence the working capacity, to unemployment, or even death. The humiliation, although concrete, is an invisible risk in the work relations and conditions. This is what Dr Margarida Barreto, a physician of the occupational medicine field, tells us in her master degree dissertation "A Journey of Humiliations"(2000). Another important author that stresses the moral hazard phenomenon is Marie-France Hirigoven, a psychoanalyst and victimology researcher; she tells us that MHT is each and every abusive conduct expressed mostly by attitudes, words, acts, gestures and writings that may bring hazard to the personality, dignity or physical integrity of the worker. It may jeopardize the job or degrade the work environment. According to this author, the worker won't die because of a relationship of cause-effect due to these aggressions, but he loses a part of his self, feeling each time more exhaust, humiliated and depressed. MHT means a suffering in the work relations, so we must consider it a disease acquired a cause of the environment in which the work activities are performed. The worker must have the right to be removed, in the same way that it happens when work-related accidents occur and the victims must have the pertinent benefits.

MHT is very common in hierarchical, authoritarian, inhuman and unethical relations. Regarding the mode that it may occurs, it can be vertical (descendent or ascendant) or horizontal; regarding the embarrassment that it may cause, it can occur among equals or workers of the same category, which is very common in competitive activities, or it can be mixed.

In Nursing, we find moral hazard in every work environments, from hospital field, to extra-hospital field and at the academy. It may occur between the health team and the nursing team, clients and families, professors and students. Probably we all have seen or we have been through this mode of hazard in our work setting.

When this humiliation/ embarrassment turns out to be repetitive, the stalker/ aggressor may disestablish both emotionally and professionally the harassed/ attacked one, in a way that he might lose the self-confidence and interest for the job. Sometimes, diseases can be initiated or worsened. Other repercussions to the victim may include isolation; in some cases lead to alcohol abuse or drug consumption, the victim may ask for demission or be demitted, even for insubordination.

For us to be able to fight against this mode of violence at work it's essential to make resistance to it, make it visible, to denounce and to document situations that we've being through or that we've been told about. We must arise against people or organizations that ignore it, that pretend that don't see or even encourage moral hazard. We should all think about if we are in the role of the aggressors or victims, and what we should do to change this situation.

Marcia Tereza Luz Lisboa

Doctor in Nursing, Associate Professor of the Anna Nery Fundamental Nursing Department of the Federal University of Rio de 


\section{EDITORIAL}

\section{ASEDIO MORAL EN EL TRABAJO DE ENFERMERÍA}

El fenómeno de sufrimiento en el trabajo es estudiado por diversas disciplinas, inclusive del punto de vista de la salud del trabajador. En enfermería tenemos algunos núcleos/grupos de investigación que trabajan con esta categoría, lo que viene contribuyendo para ampliar la producción del conocimiento en el área de la salud del trabajador de enfermería, y que tratan el adolecimiento de ese trabajador tanto de forma física cuanto psíquica.

Entretanto, el fenómeno del asedio moral fue desconocido e ignorado por muchos hasta bien poco tiempo, a pesar de ter sido impuesto a los esclavos, desde el tiempo de la colonización en nuestro país. A través de relatos de situaciones ocurridas en el ámbito de las organizaciones (actos perversos, abusivos y habituales del cotidiano) divulgados en investigaciones y en la prensa, comenzaron las discusiones y debates entre profesionales de diversas áreas sociales y científicas. Este hecho despertó también en el trabajador la motivación de la denuncia del fenómeno que está sufriendo.

En el Brasil, la primera Legislación contra el asedio moral es de Iracemápolis, San Paulo, que fue regulada a través de la promulgación de la Ley no 1.163 de 24 de abril de 2000. En los días de hoy varios avanzos legales están aconteciendo en lo que concierne a la protección al trabajador, a pesar de que todavía no exista una legislación federal.

El Asedio Moral en el Trabajo (AMT) es la exposición de trabajadores a situación humillante y vergonzosa, de carácter repetitivo y prolongado, durante la jornada de trabajo. Esta interfiere en la vida de los trabajadores de modo directo, comprometiendo su identidad, dignidad y relaciones afectivas y sociales, pudiendo ocasionar daños a la salud física y mental que pueden evolucionar para la incapacidad de trabajar, el desempleo o inclusive la muerte. La humillación, a pesar de concreta, es un riesgo invisible en las relaciones y condiciones de trabajo. Esto es lo que nos dijo la Dra Margarida Barreto, médica del trabajo, que en 2000 publicó su disertación de maestría denominada "Una Jornada de Humillaciones". Otra autora importante que aborda el fenómeno del asedio moral es Marie-France Hirigoyen, psicoanalista y victimóloga; nos dijo que el AMT es toda y cualquier conducta abusiva manifestándose, sobre todo por comportamientos, palabras, actos, gestos y escritos que puedan traer daño a la personalidad, a la dignidad o a la integridad física del trabajador, poner en peligro su empleo o degradar el ambiente de trabajo. Según esta autora, el trabajador no va morir en una relación de causa y efecto debido a esas agresiones, pero pierde parte de sí mismo, sintiéndose cada vez más exhausto, humillado y deprimido. El AMT es un sufrimiento en las relaciones de trabajo, por tanto, se debe considerarlo enfermedad adquirida en razón del ambiente en que es desarrollada la actividad, con derecho a alejamiento de forma semejante como ocurre con el accidente de trabajo y con beneficios pertinentes.

El AMT es muy común en relaciones jerárquicas y autoritarias, deshumanas y sin ética. Cuanto a la forma, puede ser vertical (descendiente o ascendiente) u horizontal; cuanto al constreñimiento puede ocurrir entre semejantes o trabajadores de la misma categoría, muy común en las actividades competitivas, o también puede ser mixta.

En enfermería encontramos el asedio moral en todos los ambientes de trabajo, desde área hospitalaria, extra-hospitalaria y en la academia. Puede ser entre colegas de equipo de salud y de enfermería, clientes y familiares, profesores y alumnos. Probablemente todos nosotros ya vimos y/o sufrimos esta forma de asedio en nuestro ambiente laboral.

Cuando esta humillación/vergüenza se vuelve repetitivo el asediador/agresor puede conseguir desestabilizar emocional y profesionalmente el asediado/agredido, de forma que pierda la autoconfianza y el interés por el trabajo, a veces, desencadenando enfermedades o agravando las pre-existentes. Otras repercusiones en la víctima pueden ser aislamiento; y en algunos casos llevar al consumo de alcohol u otras drogas, pedir demisión o ser demitido, inclusive por insubordinación.

Para que podamos luchar contra más esta forma de violencia en el trabajo es imprescindible resistir, dar visibilidad, denunciar y documentar, situaciones vividas o conocidas; oponiéndose a instituciones y personas que ignoran, fingen no ver o hasta encorajan el asedio moral. Nos resta también la reflexión si estamos en la condición de asediados o de asediadores, y lo que debemos hacer para mudar esta situación. 